\title{
Ekintzailetza sozial kooperatiboa: KoopFabrika egitasmoaren kasua
}

\section{Cooperative social entrepreneurship: the case of the KoopFabrika project}

\author{
Aritz Kanpandegi Berrotaran*, Arianne Kareaga Irazabalbeitia
}

Mondragon Unibertsitateko LANKI Kooperatibagintza Ikertegiko ikerlariak

Laburpena: Ekintzailetza soziala azken urteotan bogan dagoen praktika bat da. Berrikuntza sozial, ekonomia sozial eta enpresa sozial kontzeptuekin gertatzen den hantzera, ekintzailetza soziala ulertu eta praktikatzeko joera ezberdinak aurki ditzakegu. Ekintzailetza sozialaren korronte dominatzailea herrialde anglosaxoietako negozio eskola eta sektore filantropikoaren artean kontzeptualizatua izan den arren, badago 'bestelako' ekintzailetza sozial bat, bestelako arrazionaltasunetik abiatzen dena. Bestelako ekintzailetza hau euskal kooperatibagintza eta herrigintzaren tradiziotik abiatzen da eta Ekintzailetza Sozial Kooperatibo bezala izendatzea proposatzen da. Artikulu honetan Ekintzailetza Sozial Kooperatiboaren oinarri eta ezaugarri nagusiak aztertzen dira.

Horretarako, KoopFabrika egitasmoaren kasu azterketa (Yin, 1994) aurkezten da artikulu honetan. KoopFabrika ekintzailetza soziala sustatzea helburu duen lankidetza programa da. Egitasmoa Mondragon Unibertsitateko Lanki ikertegiak, Olatukoop sareak eta Euskal Herriko Unibertsitateko Gezki institutuak antolatzen dute eta Gipuzkoako Foru Aldundiaren babesa jasotzen du.

Hitz gakoak: Ekintzailetza soziala, Berrikuntza soziala, Ekonomia soziala, Kooperatibagintza.

\begin{abstract}
Social entrepreneurship has come into fashion in recent years. Just like with the concepts of social innovation, social economy and social business, one can observe different ways of understanding and practising social entrepreneurship. Although social entrepreneurship's dominant current was designed between business schools and the philanthropic sector in Anglo-Saxon countries, there is also "another" social entrepreneurship based on a different logic. This alternative entrepreneurship is based on the tradition of Basque social movement and cooperativism. As a name, the term Cooperative Social Entrepreneurship was suggested. This article analyses the foundation and main features of Cooperative Social Entrepreneurship.

To this end, it provides the KoopFabrika project case study (Yin, 1994). KoopFabrika is a cooperative project whose purpose is to promote social entrepreneurship. This is a project conducted by the Lanki Institute of Mondragon Unibertsitatea, the Olatukoop network and the Gezki Institute of the University of the Basque Country/Euskal Herriko Unibertsitatea.
\end{abstract}

Keywords: Social entrepreneurship, social innovation, social economy, cooperativism.

Claves Econlit: 1250, O350, P130, L260

\footnotetext{
* Harremanetan jartzeko/Corresponding author: Aritz Kanpandegi Berrotaran. Mondragon Unibertsitateko LANKI Kooperatibagintza Ikertegia - akanpandegi@mondragon.edu - https://orcid.org/0000-0001-6885-4115

Nola aipatu/How to cite: Kanpandegi Berrotaran, Aritz; Kareaga Irazabalbeitia, Arianne (2019). «Ekintzailetza sozial kooperatiboa: KoopFabrika egitasmoaren kasua», Gizarte Ekonomiaren Euskal Aldizkaria/Revista Vasca de Economía Social, 16 129-147. (https://doi.org/10.1387/reves.20924).
}

Jasoa: 10 ekaina, 2019; onartua: 30 iraila, 2019.

ISSN 1698-7446 - eISSN 2444-3107 / (C) 2019 UPV/EHU

(c) (i) Obra hau Creative Commons Atribución 4.0 Internacional-en 


\section{Sarrera}

Ekintzailetza soziala azken hamarkadetan bogan jarri den kontzeptua da, berrikuntza teknologikoan oinarritutako ekintzailetza eredutik eta negozio-ekintzailetza jardueretatik ezberdintzen dena. Berrikuntza sozial, ekonomia sozial eta enpresa sozial kontzeptuekin gertatzen den hantzera (Laville, 2014; Defourny eta Nyssens, 2011, 2013), ekintzailetza soziala ulertu eta praktikatzeko joera ezberdinak aurki ditzakegu.

Ekintzailetza sozialaren gorakada hau ez da modu isolatuan eman eta marko zabalago baten baitan kokatu dezakegu. Azken hamarkadetako erronka sozial eta ingurumen-erronkei aurre egiteko asmoz, «ekonomia berrien» olatua sortu da (Arin, 2017): ekonomia kolaboratiboa, ekonomia zirkularra, Economía del Bien Común (EBC) bezalako mugimendu sortu-berriak tradizio zabalagoa duten ekonomia sozial, enpresa sozial eta ekonomia solidarioarekin harremanean jartzen dira. Adierazpen guzti hauek paradigma berriak sortzen dituzte, egungo eredu ekonomiko dominatzailea kuestionatuz eta dimentsio soziala balioan jarriz (Chaves eta Monzón, 2018). Ekintzailetza sozialaren gorakada ere paradigma berri honen baitan kokatzen da.

Ekintzailetza soziala mundu globalean zabalduta dagoen praktika da eta herrialde askotan aurki ditzakegu esparru honetan dabiltzan eragile erreferentzialak: Amerikako Estatu Batuak, Erresuma Batua, Frantzia, Belgika, Herbehereak, Australia, Kenya, India, Txina eta abar luze bat. Baina, fokoa euskal gizartean jartzen badugu, nola ulertu eta praktikatzen da ekintzailetza soziala Euskal Herrian? Euskal gizartetik begiratuta, zeintzuk dira ekintzailetza soziala definitzen duten ezaugarri nagusiak? Galdera hauetan sakontzeko asmoz sortzen da artikulu hau.

Honenbestez, honela egituratzen da artikulu hau: hurrengo atalean, ekintzailetza sozialaren inguruko hurbilpen kontzeptuala egiten da gaur arte publikatu diren artikulu akademiko esanguratsuenen errebisioa eginez. Hirugarren atalean artikuluaren oinarri metodologikoa zehazten da. Laugarren atalean, elkarrizketa irekien erronda batean oinarritzen den diskurtsu analisi bat osatzen da, ekintzailetza sozialaren oinarri nagusietan sakonduz. Bostgarren atalean, ekintzailetza sozial kooperatiboa zedarritzen da. Seigarren eta azken atalean, ikerketa honen ondorio nagusiak jasotzen dira.

\section{Ekintzailetza soziala}

Azken bi hamarkada hauetan hainbat praktika eta kontzeptualizazio berri sortu dira kooperatibagintzaren eta ekonomia sozialaren inguruan (Chaves eta Monzón, 2018). Ekintzailetza soziala bada ere gaur egun gorantza datorren praktika hauetako bat. Ekintzailetza sozialaren gorakada 
honek narratiba berriak sortu ditu ekonomia sozialaren bueltan (Toledano, 2011) eta ekonomia sozialaren eta ekintzailetza sozialaren arteko lotura agerikoa da (Sanchiz Palacio, 2010; Enciso, Gomez eta Mugarra, 2012).

Ekintzailetza sozialaren unibertsoaren baitan askotariko korronte eta hurbilpenak aurki ditzakegu. Badago, bereziki lurralde anglosaxoietan, kontzeptualizatzen den ekintzailetza sozialaren korronte dominatzaile bat. Korronte hau aurreko mendeko 90. Hamarkadan hasten da kontzeptualizatzen negozio eskola esanguratsuenen eta sektore filantropikoaren artean: Stanford, Harvard Business School, Duke University, University of Oxford, University Pennsylvania, Skoll foundation, Schwab foundation, Kauffman Foundation etab. Korronte honek ekintzailetza soziala ohiko ekintzailetzaren «azpi-sektore» gisara definitzen du eta autore asko aritu dira ekintzailetza enpresariala eta ekintzailetza sozialaren arteko ezberdintasunak aztertzen (Austin et al., 2006; Martin et al., 2007; Drayton, 2002; Shaw et al., 2007). Eskola honen arabera, kontsideratzen da ekintzailetza sozialak bere egiten duela enpresaren mundutik datorren 'know-how'-a, baina irabaziak lortzeko bokazioz baino, arazo sozialak konpontzeko asmoz jarduten duela (Pomerantz, 2003; Mort et al., 2003; Austin et al., 2006; Boschee, 1998; Reis et al., 1999). Honen adibide gisa, Abu-Saifanek proposatzen duen definizioa hartu dezakegu:

"The social entrepreneur is a mission-driven individual who uses a set of entrepreneurial behaviours to deliver a social value to the less privileged, all through an entrepreneurially oriented entity that is financially independent, self-sufficient, or sustainable.» (Abu-Saifan, 2012)

Ekintzailetza sozialaren korronte dominatzaile horretaz gain, badira bestelako arrazionaltasunetatik abiatzen diren korronteak ere. Garapen komunitarioaren paradigmatik, ekintzailetza soziala komunitatearen logiketan kokatzen da, tokiko kapital sozialari, komunitateko kideen parte-hartzeari eta ikasketa kolektibozko prozesuei hertsiki lotuta (Peredo eta Chrisman, 2006). Korronte honen arabera, ekimen sozio-ekonomiko hauek lidergo kolektiboetan oinarritzen dira (Selsky eta Smith, 1994) eta helburu bakarra izan ordez, askotariko helburuak izaten dituzte: sozialak, ekonomikoak, kulturalak eta ingurune naturalari loturikoak (Peredo eta Chrisman, 2006). Ekintzailetza soziala tresna gisa irudikatzen da, eraldaketa sozialaren norabidean doazen anbizio handiagoko helburuak lortzeko lagungarri dena (Alvord, Brown eta Letts, 2004).

Azken ikuspegi honi oso lotuta ageri da ere kooperatibagintzaren paradigmatik abiatzen den ekintzailetza sozialaren kontzeptualizazioa. Clamp eta Alhamisek (2010) ekintzaile kooperatibo eta sozialak ezaugarritzen dituzte: (1) aukerak topatzen dituzte ekonomia berri honetan, (2) bokazio eta 
portaera ekintzaileak dituzte, (3) ekonomia eta komunitatea konektatzeko gai den lidergo kolaboratzailea errazten dute, (4) epe luzerako begiradan lan egiten dute eta (5) taldean lan egiten ohituak daude, elkarren arteko rol osagarriak garatuz. Ekimen sozio-ekonomikoak abian jartzeaz gain, ekintzailetza sozialak dimentsio zabalago batean ere eragiten du tokiko lurraldean. Mondragoneko kooperatiba esperientzia aztertuz, ikus daiteke ekintzailetza kooperatiboaren inpaktua ez dela kooperatiba berriak sortzera mugatzen, eta lurralde garapenean ere ekarpen estrategikoak egin dituela kooperatiba esperientzia honek (Lizarralde eta Irizar, 2005; Sotil, 2012).

Hortaz, argi ikusten da ekintzailetza sozialaren baitan korronte eta ikuskera ezberdinak barne-biltzen direla. Ikuskera eta arrazionaltasun ezberdin hauen jatorria XIX. mendean kokatzen du Lavillek (2014), garaian ematen den Estatu, merkatu eta gizarte zibilaren arteko solidaritatearen konfigurazio berrian: alde batetik, solidaritate demokratikoa ematen da, eskubide sozialetan, berdintasunean, birbanaketa publikoan, ekintza kolektiboan eta mugimendu sozialetan oinarrituta; eta bestetik, solidaritate filantropikoa, pobreziaren aurkako borrokan, alde-bakarreko donazioetan, birbanaketa pribatuan eta herritarren borondatezko ekintzetan oinarritutakoa. Analisi honetatik abiatuz, autoreak berrikuntza sozialaren unibertsoa bi konstelazio nagusietan banatzen ditu: bata, a) garaiko erronka sozial eta askotariko krisiei erantzun kolektiboak bilatzen dutena, solidaritate sendoan oinarritzen diren lankidetza harremanetan oinarrituta eta justizia soziala bilatzen duena; eta bestea b) solidaritate ahulago baten baitan, egungo sistemaren arazoak atontzea bilatzen duena, egungo sistema ekonomikoa ezbaian jarri gabe. Aurrenak, gizartea eraldatzea helburu duen heinean, bigarrenak gizartea hobetzea edo atontzea.

Ekintzailetza sozialaren korronte hegemonikoa solidaritate filantropikoan kokatzen den heinean (Laville, 2014), badago bestelako ekintzailetza sozial bat. Bestelako ekintzailetza sozial hori paradigma komunitario eta kooperatiboan kokatzen da eta solidaritate demokratikoan oinarritzen da. Hain justu ere, artikulu honen helburua da 'bestelako' ekintzailetza sozial hori aztertzea.

\section{Metodologiaren deskribapena}

'Bestelako' ekintzailetza sozial hori aztertzeko, ekintzailetza soziala sustatzea helburu duen programa baten kasu analisia burutu da (Yin, 1994). KoopFabrika, Euskal Herrian ekintzailetza soziala sustatzeko bokazioa duen lankidetza ekimen bat da, Mondragon Unibertsitateko Lanki ikertegiak, Olatukoop sareak eta Euskal Herriko Unibertsitateko Gezki institutuak antolatuta, Gipuzkoako Foru Aldundiaren babes eta finantzazioarekin. KoopFabrika 2016ko urtarrilean abiatu zen eta orduz geroztik 144 pertso- 
nek jaso dute ekintzailetza sozialean jarduteko formazio eta akonpainamendua eta hortik 37 aktibitate sozio-ekonomiko kontsolidatu dira, zeinetan 60 pertsonek egiten duen lan. Horrez gain, KoopFabrikaren saretze estrategiaren ondorioz, programa honetan 39 erakundeetako 65 pertsonek parte hartu dute sustatzaile eta bidelagunei bideratutako formazioetan ${ }^{1}$.

KoopFabrikaren kasu analisian sakontzeko elkarrizketa irekiak burutu dira. Elkarrizketatuak aukeratzerako orduan, profil kualifikatuen aldeko autua egin da (Alonso Benito, 2015). Bi kriterio nagusi erabili dira elkarrizketatuen profilak aukeratzeko orduan: KoopFabrikan modu kualifikatuan parte-hartu izana eta ekintzailetza sozial eta kooperatiboaren esparruan adituak edo arituak izatea. Guztira, bederatzi elkarrizketa osatu dira. Jarraian ageri den taulan zehazten dira elkarrizketa irekietan parte-hartu duten profilak.

\begin{tabular}{c|l|l}
\hline Kodigoa & \multicolumn{1}{|c|}{ Metodoa } & \multicolumn{1}{c}{ Profila } \\
\hline E-01 & Elkarrizketa irekia & $\begin{array}{l}\text { KoopFabrikaren talde sustatzaileko kidea. Kooperatibista } \\
\text { teknologia berrien sektorean (Euskal Herria). Gizonezkoa. }\end{array}$ \\
\hline E-02 & Elkarrizketa irekia & $\begin{array}{l}\text { KoopFabrikan formatzaile rolean aritua. Kooperatibista } \\
\text { komunikazioaren sektorean (Katalunia). Gizonezkoa. }\end{array}$ \\
\hline E-04 & Elkarrizketa irekia & $\begin{array}{l}\text { KoopFabrikan formatzaile rolean aritua. Ekintzailea osa- } \\
\text { sunaren sektorean (Euskal Herria). Gizonezkoa. }\end{array}$ \\
\hline E-05 & Elkarrizketa irekia & $\begin{array}{l}\text { KoopFabrikan formatzaile rolean aritua. Kooperatibista } \\
\text { komunikazioaren sektorean (Katalunia). Gizonezkoa. }\end{array}$ \\
\hline E-06 & Elkarrizketa irekia & $\begin{array}{l}\text { KoopFabrikaren talde sustatzaileko kidea. Kooperatibista } \\
\text { elikadura burujabetzaren sektorean (Euskal Herria). Ema- } \\
\text { kumezkoa. }\end{array}$ \\
\hline E-07 & Elkarrizketa irekia & $\begin{array}{l}\text { Ekintzailetzan aditua. Kooperatibista hezkuntzaren sekto- } \\
\text { rean (Euskal Herria). Gizonezkoa. }\end{array}$ \\
\hline E-08 & Elkarrizketa irekia & $\begin{array}{l}\text { KoopFabrikan formatzaile rolean aritua. Kooperatibista } \\
\text { komunikazioaren sektorean (Euskal Herria). Gizonezkoa. }\end{array}$ \\
\hline Elkarrizketa irekia & $\begin{array}{l}\text { KoopFabrikan formatzaile rolean aritua. Kooperatibista } \\
\text { tokiko garapenaren sektorean (Euskal Herria). Gizonez- } \\
\text { koa. }\end{array}$ \\
\hline
\end{tabular}

${ }^{1}$ KoopFabrikaren web gunetik jasotako datuak https://koopfabrika.eus (2019ko ekainean kontsultatuta). 
Elkarrizketa irekietan jasotako datuekin diskurtso analisia burutu da hauetan jasotzen diren narratiba nagusiak identifikatu eta ezaugarritzeko. Bederatzi elkarrizketa ireki hauek transkribatu egin dira, ondoren, bertan agertzen diren ideia, narratiba eta ezaugarriak identifikatu eta multzokatzeko. Horrez gain, ikertzaileen behaketa partehartzailean jasotako datuekin ere osatu eta kontrastatu da ikerketa.

\section{Ekintzailetza sozial kooperatiboaren oinarriak}

Bigarren atalean azaldu bezala, badago 'bestelako' ekintzailetza sozial bat, bere jarduna eta bere marko erreferentziala solidaritate demokratikoan errotuz, bere praktika eta arrazionaltasun propioak dituena. Bestelako ekintzailetza sozial hau Ekintzailetza Sozial Kooperatibo gisa izendatzea proposatzen da. Atal honetan arakatzen dira zeintzuk diren ekintzailetza sozial kooperatiboaren oinarriak.

Elkarrizketa irekien diskurtso analisitik ekintzailetza sozial kooperatiboaren sakoneko indar edo motore nagusi hauek identifikatzen dira: eraldaketa sozialaren utopiak ureztatzen dituen ekimenak dira; lana izaten da proiektu berri hauek abiatzeko motibazio nagusia, baina ez edozein lan; eta balioan jartzean da taldean ekitea eta lanaren dimentsio kolektiboa.

\subsection{Lehen motorea: eraldaketa sozialaren utopiak ureztatzen ditu ekintzailetza sozialeko ekimen hauek}

Ekintzailetza sozialeko ekimenak abiatzen dituzten norbanako eta kolektiboentzat eraldaketa soziala motibazio transzendental bat izan ohi da, lanari eta egunerokotasunari zentzua ematen diona. Horrela, gisa honetako kooperatiba eta bestelako ekimen sozio-ekonomiko berrietan ohikoak izaten dira gizarte justuago eta mundu hobeagoa eraikitzeko ametsarekin bat egiten duten pertsonak aurkitzea.

"Cuando damos el salto a imaginarnos proyectos de emprendizaje social es deseable que como punto de partida, o bien que esté incorporado dentro del proceso, el entender la necesidad de orientar lo que se está haciendo en relación a una necesidad transformadora a largo plazo.» (E-03)

Herri mugimendu eta herrigintzaren logiketan ere aurki dezakegu eraldaketa sozialerako bokazio hau, baina herri mugimenduekin alderatuz, ekintzailetza sozialak badu ezaugarri nagusi bat: eraldaketa sozialerako bidea enpresa aktibitateen bidez egin nahi da, hau da, proiektu sozio-ekono- 
mikoak garatuz. Ekintzailetza sozialean bestelako ekonomia bat praktikatuz nahi da gaur egungo sistema aldatu eta gizarte hobeago eta justuagoa eraiki.

"Gu behintzat saiatzen gea argi eukitzen mundua aldatu nahi deula enpresak sortuz, edo gauza berriak sortuz. Nik ustet mundua aldatzeko enpresak aldatu behar ditugula. (...) Nik nabi badet hemengo joko arauak aldatu, enpresa bidez aldatuko ditut.» (E-07)

Gizarte hobeagoa eraiki nahi da enpresa jardueren bidez, baina kontutan hartu behar da hasiberriak diren kooperatiba edo ekimen sozio-ekonomikoentzat eraldaketa sozialerako bokazioak blokeo efektu bat ere sor dezakeela. Hasiera horretan, arriskua dago utopiak eguneroko dinamika ito dezan, langa altuegi jarri delako. Beraz, eraldaketa sozial bokazioa bai, baina lagungarria da eraldaketa sozialaren bi dimentsioak ezberdintzea: erreferentziazko markoa (utopia) eta eguneroko dinamika (proiektua).

"(Quienes vayan a crear su cooperativa) que tengan claro que vamos a obrar en un mundo absolutamente hostil. Y esta hostilidad nos tiene que endurecer, no en el mal sentido, sino blindar de alguna forma. Nos tiene que hacer madurar. Ser conscientes de que el modelo nitido sea un estimulo, ¿no? Pero una cosa es que será un estímulo, que nos refuerce en relación al sentido de fondo que debería tener que ver con lo que queremos construir, pero que no sea una fuente de frustración.» (E-03)

Ekintzailetza sozialean beharrezkoa da utopiaren eta egunerokotasunaren artean etengabe zubiak eraikitzea. Eraldaketa sozial bokazioak prozesu-pizgarri izan behar du eta ez frustrazio-iturri. Ekintzailetza sozialean, ohikoa da lehen urteetan desmotibazio fase bat bizitzea; ez bakarrik egunerokotasunak dakartzan gogortasun guztiengatik (ohiko ekintzailetzan ere gertatzen den bezala), baita hasierako proiektu-ideiatik eta amets-utopikotik urruntze sentsazioa sortu daitekeelako ere.

"Es muy fácil la descripción del modelo de referencia, pero ese modelo de referencia inevitablemente debe contrastarse con la realidad en el corto, medio, largo plazo. Eso es imprescindible. Porque es que además esto es una escuela. A mi me parece imprescindible una referencia al modelo nitido, pero que eso no sea fuente de frustración. Ser conscientes de que el modelo nítido sea un estimulo, que nos refuerce en relación al sentido de fondo de lo que queremos construir.» (E-03)

Etengabeko oreka-desorekan bizi dira proiektu hauek, eraldaketa sozialaren erreferentziazko markoaren eta egunerokotasunean proiektuak hartzen duen norabidearen artean dantzan. Akaso horregatik, oro har, 
ekintzaile sozialek perfil bikoitz oso interesgarria azaldu ohi dute, eguneroko praktika konkretuak epe luzerako ametsekin gurutzatzen dituztelako. Ameslari praktikoak dira, utopiko-errealistak.

Amets utopikoa eta egunerokotasuna ahalik eta koherentzia gehienez lotzen saiatzen dira ekintzaile sozialak, baina bide horretan tentsioak sortzen dira. Eraldaketa ametsaren eta proiektuaren artean sor daitezkeen tentsioak naturaltasunez bizi behar dira, kontraesanak barneratzen ikasi eta modu naturalean horrekin bizitzen jakin. Kontraesan hauek bizitzea pertsonalki eta kolektiboki hazteko modu bat izan daiteke, kontzientzia maila garatzen joateko aukera bat. Kontraesanek proiektuak indartu ditzakete, pertsonak garatu.

Beraz, eraldaketa soziala ez da hasieratik proiektuek bete beharreko baldintza zurrun gisa ulertu behar, etengabeko desideratum gisa baizik; garrantzitsua da prozesu izaeran kokatzea, pertsona, talde eta komunitateen heltze eta madurazio prozesu gisa. Eraldaketa sozialerako bokazioa duten proiektuak trebatze eta ahalduntze prozesuak izan ohi dira.

Eraldaketa soziala ulertzeko orduan, gris eskala oso bat zabaltzen da: alde batean, oso diskurtso ideologizatu bat partekatzen duten ekimenak aurki ditzakegu. Bestean, eraldaketa sozialerako ikuspegia lausotuagoa duten ekimen sozio-ekonomikoak.

"Yo creo que tú puedes tener la propiedad colectiva, la gestión democrática, no buscar el lucro, si por ejemplo se busca un puesto de trabajo minimamente digno, socialmente ser responsable y no por ello pretender con tu proyecto transformar la sociedad. También hay otra versión más ideologizada: además, quiero que sea transformadora, y revolucionaria, pero sé consciente de que cada vez que añadimos algo más, o te quedas en la retórica o si alguien no se lo cree se aparta.» (E-02)

"Guk ez genun nabi jendeak gugana jotzea alternatibotzat zeatzen genulako gure burua. Guk nahi genun izan ideia honekin: onak, ez dakit, jatorrak... eta nahizun guztia eta hori izan gauzak beste modu batera eginda. Gauzak beste modura batera egiten ditugu hori bakarrik. Jendea ez dadila etorri gugana etiketa eraldatzaileakin goazelako.» (E-08)

Bestelako ekintzailetza sozial honen lehen oinarria, beraz, eraldaketa sozialerako bokazioa da; izan modu pragmatikoan ulertuta, izan modu utopikoagoan interpretatua.

\subsection{Bigarren motorea: lana da proiektu berriak abiatzeko motibazio nagusia, baina ez edozein lan}

Ohiko ekintzailetzan gertatzen den bezala, lana edukitzeko premiak bultzatzen ditu ekintzailetza sozialeko proiektuak. Baina bi ezberdintasun 
nagusi ematen dira ekintzailetza sozialean: 1/ oro har, lana duintasunez bizitzeko bitarteko gisa ulertzen da eta ez dago lanarekin aberasteko asmorik eta 2/ barrura begira, demokrazia ekonomikoaren logiketan funtzionatzen duten lan egituretan lan egiteko asmoa, ahalik eta horizontalenak diren antolamendu ereduak bilatuz.

"Ekintzailetza orokorrak, ematen du atzean nolabait badaukala bonbazoa izan eta ekonomikoki hazteko aukera edo amets hori. Ta nik uste, ez guk ta ez holako proiektuak martxan jarri dun inork, inongo momentuan ez duela bilatu aberastea, baizik eta ustet bizigarritasun hori. Hau da, duintasun minimo batekin ekonomikoki, pozik zoriontsu eta komunitatean eroso egonda bizi ahal izatea. Eta hori lortu degu.» (E-08)

«Soldata gure ustez duin baina aldi berean xumeak ditugu.» (E-08)

Ekintzailetza hauek konektatzen dute lan esparruan ere 'bestelako' logikekin funtzionatzearen inpultsuarekin. Elkarren arteko lehian oinarritzen diren merkatu logikak gainditu nahi dira, demokrazia ekonomikoaren logiketara jauzi eginez; lehiatik lankidetzara, autoritarismotik auto-eraketara, injustizietatik balio demokratikoetara.

"Guk baditugu balio batzuk, funtzionatzeko modu bat, komodo sentiarazten gaituna, gustatzen zaiguna eta nahi degu lan egin horrela. Ze horrela kontraesan gutxiago ditugu, gustorago gaude lanean, eta gainera iten ditugun proiektuekin identifikatuago sentitzen gea.» (E-08)

Asmo eta motibazio horien atzean askotan egon ohi da aurreko lan esperientzia negatibo bat, lan esperientzia txar bat: laneko arduradun autoritarioekin gatazkak, norberaren balioekin bat ez datozen lan esperientziak, norberarentzat gustukoak ez diren sektorean lanean aritzea etab. Horrelakoetan, lan egoera kaskar horiek desmotibatzaile eta frustrazio iturri izan ordez, eraldaketarako motore izatera pasatzen dira eta proiektu berriak ekiteko pizgarri bilakatzen dira. Kooperatibagintzaren balio demokratikoarekin bat egiten duten askok aurretik bizi izan dute arduradun oso autoritarioekin lan egitea zer den eta horrek balioan jartzen du enpresa barruko erabakimen espazioak demokratizatzeko bokazioa. Beste behin ere, auto-eraketaren paradigmarekin topo egiten dugu hemen, norberaren bizitzaren ardura norberak bere gain hartzeko konpromisoarekin.

«Kooperatiba sortu genun hirurak lanean egonda, beste proiektu batzutan lanean egonda. Eta gauza zan gu hirurak ez gendela bereziki gustora gure lanekin, zala baldintzengatik edo zala ez gentozelako bat proiektu 
hoien ildoekin edo proiektu hoietan tokatzen zitzaizkigun lanekin, ez ginalako oso komodo sentitzen.» (E-08)

Bestelako ekintzailetza sozial honen bigarren motorea lan aukera duin eta koherenteak sortzea da. Inpultsu honek bete-betean konektatzen du kooperatibagintzaren sustraiekin eta auto-eraketaren paradigmarekin: "guk geuk sor dezagun guretzat nahi dugun hori, inori ezer eskatzen ibili ordez».

\subsection{Hirugarren motorea: taldean ekitea eta lanaren dimentsio kolektiboa}

Ekintzailetza sozialean badago beste indar edo motore oso potente bat: era kolektibo batean ekiteko bokazioa. Badago gauzak egiteko asmoa eta gogoa, baina batez ere, kolektibo baten baitan ekimen berriak garatzekoa.

"Zeren badago jende asko nahi dula beste modu batera lan egin, beste proiektu mota batean, jendarteari beste zerbait eragingo diona, kolektiboa izango dana... Niri askok esan didate: "nik hau egingo det aurkitzen badet lantalde bat.» (E-01)

Kolektibotasun horretatik eraikitzen dira prozesu sozio-ekonomiko berriak. Aurreneko atalean azaltzen diren ekintzailetza soziala ulertzeko bi moduen artean, hau izan daiteke ezaugarri bereizgarrienetakoa (bai plano diskurtsiboan nola praktikoan): ekintzailetza sozialaren korronte hegemoniko anglosaxoiak pertsona indibidualetan jartzen badu enfasia, auto-eraketatik sortzen den ekintzailetza sozialak bere izaera kolektiboan jartzen du fokoa. Klabe kolektiboan lan egite honen baitan, bi dimentsio nagusi ezberdindu daitezke: taldea eta komunitatea.

Taldeak garrantzi estrategikoa du ekintzailetza sozialean. Kapital sozialaren perspektibarekin bat eginez, proiektuak garatzea bezain garrantzitsua da kolektibo berrien artean sortzen diren harreman eta kohesioak. Taldeko kideen arteko harremanak presentzia handia hartzen du ekintzailetza sozialean eta balio oso garrantzitsu bezala kontsideratzen da. Taldeak ematen dio zentzua proiektuari.

"Gure proiektuak zentzua du taldeagatik. Esan nabi det, osea, inondik inora gutako inork banaka ez luke holako ezer sortuko. (...) gure proiektua kolektiboa da ta kolektiboa da inkluso proiektuaren gainetik. Momentu baten ikusiko bagenu gure bizitza, gure arteko harremanak ta gure bizitzak kaltetzen ditula proiektuak, ba bertan behera utziko genuke. Ez gaitu proiektuak egiten taldea, baizik ta taldeak proiektua.» (E-08) 
Horren ondorioz, ekintzailetza sozialean pertsonen arteko zaintzak garrantzia handia du, batez ere, taldekideen artekoak. Ekintzailetza sozialean badira ekonomia feministaren markoa bere egiten dutenak eta balio handia ematen diotenak harremanen dimentsioari. Talde lanean aritzea bada funtzio eta ardurak partekatzea, baina bada ere, elkarren arteko zaintza. Ekonomia egiteko bestelako eredu hau elkarren arteko zaintzan ere gauzatzen da.

"Nosotros también entendemos que todo el tema de la sostenibilidad colectiva es también importante. Porque, ¿cuántas cooperativas de compañeros hemos tenido tremendamente exitosas, que profesionalmente se han roto por discusiones? También hay que pensar que toda la viabilidad empresarial es importante pero que toda la sostenibilidad social o societaria o la dimensión más humana de los equipos tiene que estar en la primera línea también." (E-05)

Honek eramaten gaitu, nolabait, ekintzailetza sozialaren fokoa zabaltzera. Ohiko ekintzailetza ereduak arreta osoa proiektuan jartzen du, batez ere, proiektu-merkatu harreman horretan; eta pertsonak proiektu horiek gauzatzeko 'baliabideak' besterik ez dira. Baina ekintzailetza sozial honek fokoa zabaldu eta proiektuari bezain garrantzi handia ematen dio taldeari ere. Prozesu logika batean kokatuz, bata zein besteari eman beharko diogu garrantzia bera: bai proiektuaren garapen eta eboluzioari, baita taldearen kohesio eta madurazio prozesuari ere.

"Horregatik, ezberdindu beharko dugu nolakoa izaten ari den taldearen madurazio prozesua eta bestetik, nolakoa izaten ari den proiektuaren materializazioaren prozesua. Askotan erlazionaturik dauden arren, bi prozesu ezberdin izan ohi dira.» (Mauge Cañada-KoopFabrikako formakuntza saioan-2017ko martxoak 21)

Lan-taldeak balio estrategikoa du ekintzailetza sozialean eta taldearen zaintza ezinbestekoa da proiektu hauen bideragarritasunean. Baina kolektiboan ekiteak talde dimentsioa gainditzen du eta beste dimentsio batean ere eragiten du: komunitate edo sare zabalago batean ere harremantzea. Ekintzailetza sozialeko proiektuak ez dira modu isolatuan aritzen eta naturalki jotzen dute sare baten baitan ekitera. Ekimen sozio-ekonomiko hauek biltzen dituzten sareak anitzak izan daitezke: tokikoak, sektorialak, globalak... Baina oro har, tokiko eragileekin harremantzera jotzen dute ekintzailetza sozialeko proiektuek (herrian, eskualdean, lurraldean), tokiko ekosistemak sortuz edo indartuz.

Hainbat kasutan, komunitateak berak ematen dio zentzua ekintzailetza sozialeko proiektuari. Komunitate jakin batetik abiatzen diren proiektuak 
dira eta komunitateari zor zaizkio. Komunitatea izan daiteke sorlekua, habitat naturala, sostengua, bezeroa eta bihotza.

"Gero bestetik argi geneukan gu euskal komunitateari zuzentzen ginala eta hori zala gure lan esparrua. Hori zala gehien ezagutzen genuna ta ez ginala izango enpresa generalista bat, baizik eta nabiko publiko espezifiko batekin egingo genitula gure harremanak, osea gure entorno naturalen ingo genula lana.» (E-08)

"Guretzako ekoizleak ere badira komunitatea. Batez ere bitartekariak ez baina ekoizleak bai. Ba gertutasun hori lortu degulako.» (E-06)

Elkarrizketatuen artean, nabaria da hainbat kooperatibek beraien gertuko komunitatetik jaso duten babesa (familiatik eta lagunartetik batik bat), batez ere, ekimenak martxan jartzeko lehen hilabeteetan. Kasu batzuetan, sostengu ekonomiko gisa funtzionatu du gertuko komunitate honek, besteetan, baliabideak errazteko funtzioarekin. Gertuko komunitateak eskainitako babes hori ezinbestekotzat jotzen da, eta kooperatiba sortzeko erabakia hartzeko orduan faktore oso garrantzitsu gisa kontenplatzen da.

"Komunitatian noski lagunak eta familia, osea hori aurrena. Osea hori aurrena, eta (kooperatibako) lauroi. Lauron kasuan izan da inkondizionala. Ze nik uste da, proiektua eusteko ta aurrea jarraitzeko oinarrizko baldintza.» (E-06)

Gertuko komunitate horrez gain, ekintzailetza sozialean ere sortzen da beste komunitate mota bat, kooperatiba edo ekimen ezberdinak saretzen dituen komunitatea hain zuzen ere. Berdinen arteko sistema hauetan, pertenentzia zentzuak presentzia handia du. Bakoitza bere egunerokotasunean aritzeaz gain, proiektu edo taldeek babesa sentitzen dute hantzeko ezinegonak dauzkaten eta bizitza egoera igualtsuetan dauden beste pertsonekin espazio bat partekatzean. Kodigo eta egiteko amankomunak partekatzen dira eta komunitateak tribu izaera hartzen du. Honen adibide dugu KoopFabrika: programa honetan parte-hartzen duten ekintzaileek asko baloratzen dute beraien egoera hantzekoan dauden beste pertsonak ezagutzea eta modu iraunkor batean harreman hori mantentzea.

Beraz, ekintzailetza sozialaz ari garenean, komunitate hitzak esanahi ezberdinak biltzen ditu bere baitan: a) gizarteko sektore zabal gisa (euskal komunitatea adibidez), b) tokiko edo oso gertuko komunitate gisa (auzoa, herria, familia edo lagunartea) eta c) berdinen arteko sare gisa (KoopFabrika).

Atal honen itxiera moduan, ondoriozta daiteke ohiko ekintzailetzarekin alderatuz, ekintzailetza sozialean fokoa zabaldu egiten dela. Ohiko 
ekintzailetzan arreta osoa proiektuan jartzen bada, ekintzailetza sozialean proiektuaren garapena bezain garrantzitsua da taldearen madurazio prozesua eta funtsezkoa da komunitate edo sare zabalagoaren babesa eta presentzia. Ekintzailetza sozialean proiektuak gauzatzeaz gain, pertsonen madurazio prozesuak ematen dira taldean eta komunitateko sareak elikatu.

\section{1. irudia}

Ekintzailetza Sozialaren hiru foko nagusiak: proiektua, taldea eta komunitatea

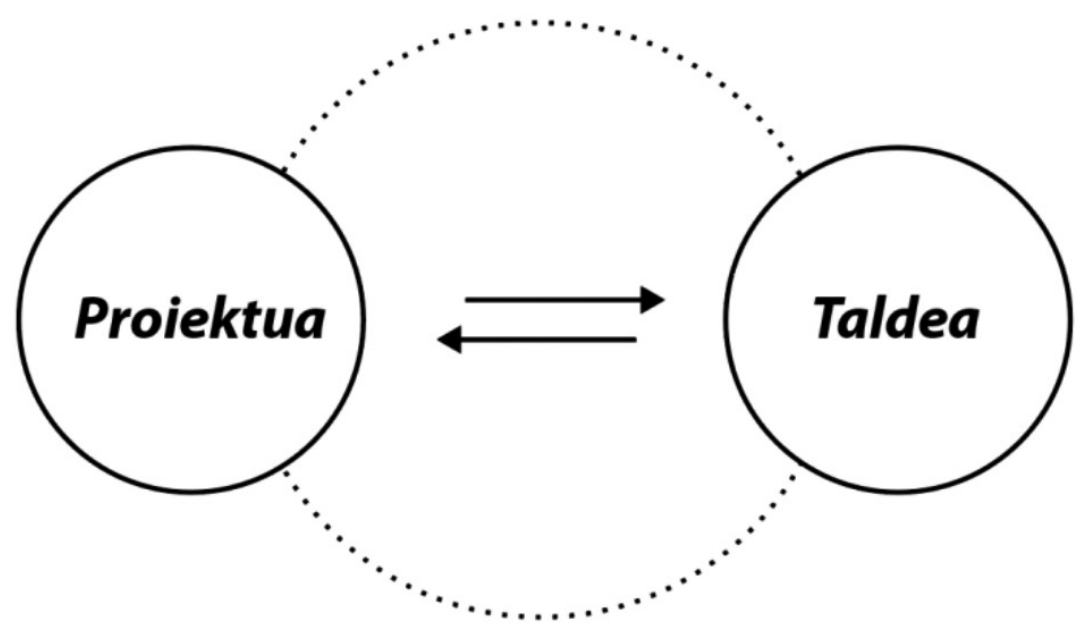

Komunitatea

Iturria: egileek sortua.

\section{Ekintzailetza Sozial Kooperatiboa zedarritzen}

Aurreko atalean garatutako ekintzailetza sozial kooperatiboaren indar edo motore nagusiek azaltzen duten bezala, 'bestelako' ekintzailetza sozial honek baditu bere praktika eta arrazionaltasun propioak. Diskurtso analisi horretatik abiatuz, atal honetan zedarritzen da Ekintzailetza Sozial Kooperatiboa, bere baitan biltzen dituen ezaugarri nagusiak islatuz:

- Kolektiboa. Modu kolektiboan lan egitea bilatzen da eta kolektibotasun hau balioan jartzen da. Bi dimentsio nagusitan uler daiteke kolektiboa: a) norbanakoa baino, talde bat delako ekimen sozio-enpresarial berriak aurrera ateratzen dituena eta b) ekimen ezberdinen artean ere badelako saretzeko eta inter-kooperaziorako bokazio argi 
bat. Ekimen sozio-ekonomiko hauek lankidetzaren paradigmatik ekiten dute.

- Autoeratua. Demokratikoa. Autoeraketaren paradigman txertatzen da ekonomia egiteko modu hau, non erabakitzeko ahalmena taldean kokatzen den. Ikerketa honetan elkarrizketatu batek dion bezala ' $\mathrm{La}$ nean erabakiak guriak dia' eta horrek bereziko garrantzia du pertsonen ahalduntzean. Gainera, erabaki-hartze prozesu hau balio demokratikoetan egiten da, taldeko kide guztien parte-hartze eskubidea bermatuz. Eredu kooperatiboan bezala, ekimen hauetan ere partehartze eta erabakimen demokratiko hau hiru esparru ezberdinetan ematen da: a) eguneroko lanean eta gestioan, b) enpresaren jabetzan eta c) aktibitateak sorturiko emaitzen banaketan.

- Bideragarria. Proiektu sozio-enpresarialak dira ekintzailetza sozial kooperatiboan biltzen direnak. Merkatuan bizi-irautea ezinbesteko duten ekimenak dira, baina merkatu logikak barneratu nahi ez dituztenak. Bideragarritasunik gabe, ez dago proiekturik, ez dago enplegurik. Ekonomikoki errentagarriak izan behar dira proiektuak (itzulkin monetarioa), baina prozesuan zehar pertsonak ere ahalduntzen doaz (itzulkin sozietarioa) eta gainera, gizartearentzat baliogarria den emaitza lortzea da asmoa (itzulkin soziala).

- Bizigarria. Bizitza zentroan jartzen da. Norberaren motibazio, zalantza eta sentimenduek ere bere lekua hartzen dute ekintzailetza molde honetan. Lan produktiboa eta erreproduktiboa uztartzen duten orekariak dira ekintzaile hauek. Etxeak badu presentzia lanean eta lanak etxean. Balioan jartzen da bizitza eta lanaren izaera instrumentala onartzen da. Laneko harremanak zaintzeari garrantzi handia ematen zaio. Lan egiteko modu bat baino, bizitzeko modu integral bat da hemen abiatzen dena, norberaren balioekin koherentzian doan lan jarduera sortzeko autua. Bizipoza edo indigenen 'sumak kawsay' oinarri duen bizitzeko modua.

- Sustraitua. Tokian Saretua. Tokiko lurraldeari lotzen zaizkion ekimen sozio-ekonomikoak dira hauek: eskualdean saretuak daudenak, berdinen arteko inter-kooperazioa praktikatzen dutenak, herriko beste eragileekin lankidetzan erronka berriei heltzen diotenak. Horrela, ekimen sozio-ekonomiko hauek tokiko komunitate batean txertatzen dira eta komunitate zabal baten babes edo sostengua sentitzen dute. Komunitate hauek sektorialak izan daitezke edo geografikoak.

-Utopiko-errealista. Eraldatzailea. Eraldaketa sozialaren utopiak elikatzen ditu ekimen sozio-ekonomiko hauek. Ortzi-mugan eraldaketa sozialerako ametsa daukate, baina eguneroko errealitatean proiektu errealak dira, bestelako ekonomia eredu bat praktikatzen 
duten ekimenak. Arestian aipatu bezala, garrantzitsua da eraldaketa sozialaren bi dimentsio hauek ezberdintzea: erreferentziazko markoa (utopia) alde batetik, eta eguneroko praktika (proiektua) bestetik; bi plano hauen artean etengabe zubiak eraiki behar direlarik.

- Ardura-hartzean oinarritua. Ekintzailetza sozial kooperatiboa zerbait bada ardura-hartze prozesu amaigabe bat da. Ardura hartzea da burujabe izateko bidea; ardura-hartzerik gabe ez dago eraldaketa sozialik, ez dago kooperatibagintza ulertzerik. Ardurak hiru dimentsiotan hartzen dira ekintzailetza sozial kooperatiboan: 1/ norbanako bakoitzak bere bizitzan hartzen dituen ardurak 2/ taldean beste kideekin batera adostutako konpromisoak 3/ proiektua komunitatean txertatzen denean komunitatearekiko eta gizartearekiko hartzen diren ardurak.

\section{2. irudia}

Ekintzailetza Sozial Kooperatiboaren ezaugarritzea

KOLEKTIBOA.

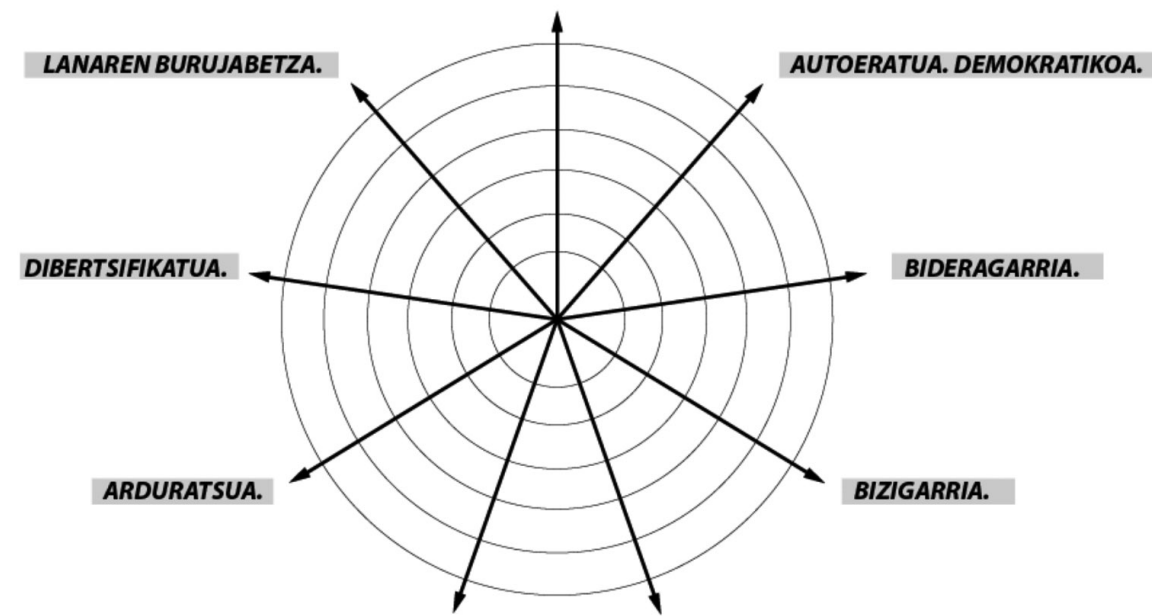

UTOPIKO-ERREALISTA. ERALDATZAILEA.

SUSTRAITUA. SARETUA.

Iturria: egileek sortua.

—Dibertsifikatua. Naturalki jotzen da enpresa edo kooperatiba beraren baitan aktibitate ezberdinak edukitzera eta ohiko enpresetan baino dibertsifikatuagoa izan ohi da zerbitzu eskaintza. Ekintzailetza sozial kooperatiboan ohiko da hiruzpalau lagunek osaturiko koo- 
peratiba batean lau aktibitate ezberdin edukitzea eta beraien artean ezberdinak, anitzak. Naturalki hartzen den bide honek badu bere estrategikotasuna: a) alde batetik, merkatuaren aldaketen aurrean askoz ere erresilienteagoak direlako eta b) bestetik, kooperatibako kide bakoitzaren motibazioa piztuta mantentzea ahalbidetzen duelako, horrela errazagoa baita motibazio pertsonalak kooperatibaren egitekoekin lotzea.

- Lanaren burujabetza. Ekintzailetza sozial kooperatiboa lanaren burujabetzaren aldeko autua da. Beste ekonomia ereduan ez bezala, hemen ez dago etekin ekonomikoekin aberasteko asmorik eta beharrak asetzera bideraturiko ekonomia da praktikan jartzen dena; batez ere, lan duina edukitzeko beharra asetzera. Baina lana modu burujabean egin nahi da, lanaren inguruko erabaki nagusiak norberaren eta kolektiboaren esku egonda: erabakiak hartzeko ardura norberarena eginez eta ez besteen esku utziz.

\section{Ondorioak}

Ekintzailetza sozialaren korronte dominatzailea herrialde anglosaxoietan errotuta dago, negozio eskolen eta sektore filantropikoaren logikak bateratuz. Korronte dominatzaile horretaz gain, artikulu honetan ikusi ahal izan den moduan, badago Ekintzailetza Sozial Kooperatibo bezala izendatu den korronte bat, praktika eta arrazionaltasun propioak dituenak. Korronte honek euskal kooperatibagintzaren eta herrigintzaren oinarriekin konektatzen du eta esan daiteke tradizio horietatik sortzen diren praktikak direla hauek. Tradizio horietatik eratorri arren, marko erreferentzial berri eta propioa eraikitzen ari dira praktika berri hauek, Ekintzailetza Sozial Kooperatiboan ezaugarritzen dena.

Ekintzailetza Sozial Kooperatiboak balioan jartzen du ekintzailetza sozialaren dimentsio kolektiboa, auto-eratu eta demokratikoa, bideragarria, bizigarria, sustraitua, utopiko-errealista, arduratsua, dibertsifikatua eta burujabea.

Ikerketa hau KoopFabrika ekimenaren markoan garatua izan da. Aurrera begira, interesgarria ikusten da ikerketa honen ondorioak elkarrizketan jartzea Euskal Herrian ekintzailetza sozialaren praktikatik hurbil egon daitezkeen bestelako ekimenekin: Mondragoneko Esperientzia Kooperatiboarekin, azken urteotan ekonomia sozialaren bueltan abian jarri diren ekimen sozio-ekonomiko esanguratsuenekin (Goiener, Labore, EreinDaJan, Otsokop, Bizilore, etab.) eta azken urteetan sortu diren hainbat kooperatiba txikiekin. 


\section{Esker onak}

Bihotzez eskertu nahi da ikerketa honetan elkarrizketatuak izan diren pertsona guztiek azaldu duten eskuzabaltasuna: benetako plazerra izan da zuekin momentu hori partekatu izana! Eskerrak ere, KoopFabrikaren komunitatea osatzen duzuen kide guztiei eta Gipuzkoako Foru Aldundiari ikerketa hau finantziatzeagatik.

\section{Bibliografia}

Abu-Saifan, S. (2012). «Social Entrepreneurship: Definition and Boundaries». Technology Innovation Management Review, vol. 2 (2).

Alonso Benito, L.E. (2015). La entrevista abierta como práctica social. En «El análisis de la realidad social: métodos y técnicas de investigación" / coord. por Manuel García Ferrando, Francisco Ricardo Alvira Martín, Luis Enrique Alonso Benito, Rafael Modesto Escobar Mercado. Págs. 390-417. Ed. Alianza.

Alvord, S.H.; Brown, L.D.; Letts, C.W. (2004). «Social Entrepreneurship and Societal Transformation an Exploratory Study». The Journal of Applied Behavioral Science, vol. 40(3), pp. 260-282.

Arin, A. (2017). «Nuevas economías transformadoras». REVES-Revista Vasca de Economía Social, 2017, núm. 14.

Austin, J.; Stevenson, H.; Wei-Skillern, J. (2006). «Social and Commercial Entrepreneurship: Same, Different, Or both?». Entrepreneurship Theory and Practice, vol. 30(1), pp. 1-22.

Boschee, J. (1998). Merging mission and money: A board member's guide to social entrepreneurship.

Chaves Ávila, R.; Monzón Campos, J.L. (2018) «La economía social ante los paradigmas económicos emergentes: innovación social, economía colaborativa, economía circular, responsabilidad social empresarial, economía del bien común, empresa social y economía solidaria». CIRIEC-España Revista de economía pública, social y cooperativa, 2018, núm. 93, pp. 5-50.

Clamp, C.A.; Alhamis, I.(2010). «Social Entrepreneurship in the Mondragon Co-Operative Corporation and the Challenges of Successful Replication». Journal of Entrepreneurship, vol. 19(2), pp. 149-177.

Dees, J.G. (1998). «The Meaning of Social Entrepreneurship». The Meaning of Social Entrepreneurship.

Dees, J.G.; Anderson, B.B. (2006). «Framing a Theory of Social Entrepreneurship: Building on Two Schools of Practice and Thought». Research on Social Entrepreneurship: Understanding and Contributing to an Emerging Field, vol. 1(3), pp. 39-66.

Defourny, J.; Nyssens, M. (2011). "Approches européennes et américaines de l'entreprise social: une perspective comparative.» Revue internationale de l'économie sociale: Recma, (319), 18-35. 
Defourny, J.; Nyssens, M. (2013). "Social innovation, social economy and social enterprise: what can the European debate tell us?.» En: The international handbook on social innovation: Collective Action, Social Learning and Transdisciplinary Research, 40-53.

Drayton, W. (2002). "The Citizen Sector: Becoming as Entrepreneurial and Competitive as Business». California Management Review, vol. 44(3), pp. 120132.

Enciso, M., Gómez, L. \& Mugarra, A. (2012). «La iniciativa comunitaria en favor del emprendimiento social y su vinculación con la economía social: una aproximación a su delimitación conceptual», CIRIEC-España, Revista de Economía Pública, Social y Cooperativa, 75, 55-80.

Laville, J.L. (2014) «Innovation sociale, économie sociale et solidaire, entrepreneuriat social. Une mise en perspective historique». En: Juan-Luis Klein éd., L'innovation sociale. Toulouse, ERES, "Sociologie économique », pp. 45-80.

Lizarralde, I.; Irizar, I. (2005). "Desarrollo Regional y Emprendizaje Cooperativo». Ekonomiaz. Revista de Economía Vasca (59), pp. 284-305.

Martin, R.L.; Osberg, S. (2007). «Social Entrepreneurship: The Case for Definition». Stanford Social Innovation Review, vol. 5(2), pp. 28-39.

Mort, G.S.; Weerawardena, J.; Carnegie, K. (2003). «Social Entrepreneurship: Towards Conceptualisation». International Journal of Nonprofit \& Voluntary Sector Marketing, 02, vol. 8(1), p. 76.

Nicholls, A. (2008). Social Entrepreneurship: New Models of Sustainable Social Change. Oxford University Press, Oxford.

Nicholls, A.; Cho, A.H. (2006). "Social Entrepreneurship: The Structuration of a Field». En: Nicholls, Alex, (ed.) Social Entrepreneurship: New Models of Sustainable Social Change. Oxford University Press, Oxford, pp. 99-118.

Peredo, A.M.; J.J. (2006). "Toward a Theory of Community-Based Enterprise». Academy of Management Review, vol. 31(2), pp. 309-328.

Pomerantz, M. (2003). The Business of Social Entrepreneurship in a» Down Economy». In Business-Emmaus Pennsylvania-, vol. 25(2), pp. 25-28.

Reis, T.; Clohesy, S. (1999). Unleashing the New Resources and Entrepreneurship for the Common Good: A Scan. Synthesis and Scenario for Action, MI: WK Kellogg Foundation, Battle Creek.

Sanchis Palacio, J.R. (2010). Emprendimiento, economia social y empleo. IUDESCOOP, Instituto Universitario de Economía Social y Cooperativa de la Universidad de Valencia, 2011.

Shaw, E.; Carter, S. (2007). «Social Entrepreneurship: Theoretical Antecedents and Empirical Analysis of Entrepreneurial Processes and Outcomes». Journal of Small Business and Enterprise Development, vol. 14(3), pp. 418-434.

Selsky, J.W.; Smith, A.E. (1994). "Community Entrepreneurship: A Framework for Social Change Leadership». The Leadership Quarterly, vol. 5 (3-4), pp. 277-296.

Sotil, J. (2012). «Cooperativas y Emprendimiento». Boletín De Estudios Económicos, vol. 67(205), pp. 161-176. 
Toledano, N. (2011). «Social Entrepreneurship: The New Narrative for the Practice of the Social Economy». CIRIEC-España, Revista de Economia Pública, Social y Cooperativa, vol. 73, pp. 9-31.

Yin, R.K. (1994). Case study research and applications: Design and methods. Applied Social Research Methods Series, Vol. 5, Second Edition, Sage publications, London. 